\title{
QUALITATIVE ASPECTS OF OOCYTES FROM NELORE AND SENEPOL BREEDS REARED IN A TROPICAL REGION
}

\author{
RODRIGUES, Janderson Aguiar ${ }^{1}$ \\ DOMICIANO, Leandro Ferreira ${ }^{1}$ \\ BORGES, Roberta Martin Gomes da Silva ${ }^{2}$ \\ RONDON, Glaudson Marcos ${ }^{3}$ \\ ROCHA, Natalia Tousube $\mathrm{da}^{4}$ \\ SOUZA, Gabriela Albano Nunes de ${ }^{4}$ \\ SOUZA JÚNIOR, Vicente Batista de ${ }^{4}$ \\ XAVIER, Maxuel Fellipe Nunes ${ }^{5}$
}

SUMMARY: The objective of this work was to evaluate the influence of the tropical climate on donor races on the quantity and quality of oocytes aspirated in Nellore and Senepol cows by means of follicular aspiration, destined to the in vitro production of embryos. The experimental design was in randomized blocks, considering each bovine female as a plot and each farm being a block totaling 14 different properties, and the number of cows used were 238 for the Nelore breed and 267 for the Senepol breed totaling 505 bovine females. The evaluation of the total number of oocytes and the quality by the quality classification of oocytes aspirated in Grade I, II, III, atresic and degenerate. The results obtained in this work, we can conclude that among the breeds evaluated, the Nelore breed was superior in total oocyte quantities and in the classification of GI and GII, being superior in the quantities of viable oocytes compared to the Senepol breed.

Keywords: Physiology. Classification of oocytes. Follicular development.

\section{ASPECTOS QUALITATIVOS DE OÓCITOS DE MATRIZES DAS RAÇAS NELORE E SENEPOL CRIADAS EM REGIÃO TROPICAL}

RESUMO: Objetivou-se avaliar neste trabalho a influência do clima tropical em raças doadoras quanto a quantidade e qualidade dos oócitos aspirados em vacas da raça Nelore e Senepol, por meio da aspiração folicular, destinados à produção in vitro de embriões. O delineamento experimental foi em blocos ao acaso, considerando cada fêmea bovina como uma parcela e cada fazenda sendo como bloco totalizando 14 propriedades diferentes, e o número de vacas utilizadas foram 238 para raça Nelore e 267 para a raça Senepol totalizando 505 fêmeas bovinas. A avaliação do número total de oócitos e da qualidade foi feita pela classificação do Complexo Cumulus Oócitos (CCOs) em Grau I, II, III, atrésicos e desnudos ou (degenerado). Os resultados obtidos no presente trabalho, podemos concluir que entre raças avaliadas, a raça Nelore foi superior na quantidade total de oócitos e na classificação de GI e GII, sendo superior na quantidade de oócitos viáveis comparara a raça Senepol.

Palavras-chave: Fisiologia. Classificação dos oócitos. Desenvolvimento folicular.

\footnotetext{
${ }^{1}$ Doutorando no Programa de Pós Graduação em Ciência Animal pela Universidade Federal de Mato Grosso/Campus Cuiabá, Cuiabá-MT, Brasil.

${ }^{2}$ Professora, Mestre em Ciência Animal do Instituto Federal de Mato Grosso/Campus São Vicente, São Vicente da Serra-MT, Brasil.

${ }^{3}$ Bacharel em Zootecnia pelo Instituto Federal de Mato Grosso/Campus São Vicente, São Vicente da Serra-MT, Brasil.

${ }^{4}$ Estudante de Bacharelado em Zootecnia pelo Instituto Federal de Mato Grosso/Campus São Vicente, São Vicente da Serra-MT, Brasil.

${ }^{5}$ Estudante de Bacharelado em Agronomia no Instituto Federal de Mato Grosso/Campus São Vicente, Centro de Referência de Campo Verde, Campo Verde-MT, Brasil.
} 


\section{INTRODUCTION}

The development of bovine breeding biotechnologies has maintained a consolidated growth in Brazil with the use of techniques such as artificial insemination, embryo transfer and in vitro embryo production, which is a fundamental tool in the genetic improvement of herds (VIANA, 2010). With this, the use of bovine breeds of high genetic aptitude is being employed in order to improve and increase animal production (MELLO et al., 2016).

Although the technique of in vitro embryo production in laboratories dates back to 1978, with the birth of Louise Brown, the "first test specimen baby", the growth and wide use of the technique in animal reproduction occurred in the latter (STEPTOE; EDWARDS, 1978; GONÇALVES et al., 2007; MELLO et al., 2016). The improvement and development of the techniques made it possible to collect, cryopreserve and transfer embryos, being able to repeat the procedure without interfering in the amount of oocytes (VARAGO; MENDONÇA; LAGARES, 2008). The optimization of the technique provided alternatives that increased the potential of females with higher genetic value, avoiding early disposal due to inability to reproduce naturally (BUENO; BELTRAN, 2008).

The oocyte, female germ cells produced in the ovaries, is involved by granular cells, forming the cumulus oopohorus complex (AGOSTINHO; LÉGA, 2009). Cumulus cells include follicle coordination and development and are essential in oocyte maturation, fecundation and embryonic development (GONÇALVES; FIGUEIREDO; FREITAS, 2002). Therefore, the existence of this cell complex is an important quality factor in oocyte maturation in vitro (AGOSTINHO; LÉGA, 2009).

The development and, consequently, the quality of the oocytes are directly associated with the physiological conditions of the donor, such as the estral cycle, follicular growth, among others (LONERGAN; FAIR, 2008). In addition, climatic factors such as high temperature and humidity may affect the quality and development of oocytes, due to the higher caloric stress especially in taurine cows with lower adaptability to tropical conditions (WARD et al., 2000). Although zebu cows also suffer from heat stress, they are more adapted and may have normal oocyte development (ROCHA et al., 1998). Thus, the quality of oocytes is compromised and fertility decreased when sensitive breeds are subjected to adverse weather conditions such as heat and high temperatures (OZAWA et al., 2005).

The greater adaptation of zebu breeds in tropical regions, characterized by warm climate, low quality fodder and high parasitic load, usually presents higher productivity compared to taurine breeds. However, zebuins breeds present smaller ovaries and corpus luteum in comparison with taurine females, resulting in fewer follicles per ovary and lower oocyte quality, 
mainly during dry months (LEAL et al., 2009). Thus, regardless of genetics, the higher number of oocytes with higher quality are obtained during the rainy season, resulting in higher conception rate (FERNANDES et al., 2001).

The objective was to evaluate the influence of donor breeds on the quantity and quality of oocytes aspirated, in Nelore and Senepol cows through follicular aspiration, intended for in vitro production of embryos in places of tropical climate.

\section{MATERIAL AND METHODS}

The oocyte samples were collected from properties located in the following municipalities of Mato Grosso, Brazil: Cáceres, Comodoro, Pontes e Lacerda, Porto Esperidião, Santo Afonso, Rio Branco, Vila Bela da Santíssima Trindade, Chapada dos Guimarães, Cuiabá, Jangada, Santo Antônio do Leverger, Barra do Garças and Rosário Oeste. The collections took place during the rainy season (January to February and September to December/2016). The climatic classification, according to Köppen's (1928) criteria, is predominantly of type Aw, that is, tropical climate with rainy season in summer and dry in winter. The average temperature varies between $22-25^{\circ} \mathrm{C}$ and annual rainfall between $1200 \mathrm{~mm}$ and $1800 \mathrm{~mm}$ (MARCUZZO, CARDOSO; FARIA, 2012).

In each property the matrices were kept in marandu grass (Urochloa brizantha cv. Marandu) supplemented with mineral salt ad libitum and protein supplement plus cyanocobalamin (vitamin B12).

All the matrices used were Pure of Origin (PO), non-lactating, of the breeds Nelore (Bos taurus indicus) and Senepol (Bos taurus taurus), with an average body score of 3.0 on a scale of 0 to 5 (LOWMAN, SCOTT; SOMERVILLE, 1976), and body weight between 350 to $450 \mathrm{~kg}$ in both breeds.

The matrices were subjected to the following hormonal protocol: Day $0=$ administration of $2 \mathrm{~mL}$ of intramuscular Estradiol Benzoate (IM) and placement of the subcutaneous auricular progestogen implant containing $3 \mathrm{mg}$ of Norgestomet (Crestar ${ }^{\circledR}$ Intervet); Day 4 = application of $2 \mathrm{~mL}$ of follicle stimulating hormone (FSH) (IM) from (Folltropin $\left.{ }^{\circledR}-\mathrm{V}\right)$; Day $5=$ application of $2 \mathrm{~mL}$ of FSH (IM) from (Folltropin $\left.{ }^{\circledR}-\mathrm{V}\right)$; Days 6 = removal of the progestogen implant and performing the follicular aspiration.

Follicular aspiration was performed by the ovum pick-up method (OPU), by the vaginal fornix, performed with the aid of ultrasound equipment (Mindray DP-20 VET) with a Bivolt transducer, coupled to a transvaginal follicular aspiration guide. The suctions were performed with a hypodermic disposable needle $(40 \times 9 \mathrm{~mm}$ long, Becton Dickson, Brazil) connected to a 50 
$\mathrm{mL}$ conical tube (Corning, USA) by a $0.8 \mathrm{~m}$ internal diameter silicone tube of $2 \mathrm{~mm}$ and suction system using a vacuum pump (BV-003D WTA-Watanabe) with adjustable vacuum pressure.

The ovaries were positioned on the puncture line indicated on the ultrasound screen and the vacuum pump was triggered by starting the aspirations of the follicles, which were stored immediately in a $50 \mathrm{~mL}$ falcon tube plus phosphate saline buffer (PBS; Dulbecco®) and heparin (50 IU/ml; Liquemine®).

The collected material, with the proper identification of the animal, was immediately transported to a mobile laboratory mounted on the property. The aspirated liquid was washed with the same storage solution (PBS and heparin), passing through a 75 micron nylon screen filter (WTA-Watanabe), washing the collected material until the content of the filter became translucent, to finally be classified.

After washing, the material was deposited in Petri dishes and with the aid of a magnifying glass (NIKON, model C-DS, Japan) the search and selection of oocytes and subsequent classification were performed.

The oocytes were classified according to the quality proposed by Lonergan et al. (1994), in degree I, II, III, naked and atretic (Table 1) based on the morphological aspect of the cumulus oophorus complex (COC) and the ooplasm. After classification, the oocytes were placed in cryotubes where they contain a means of maturation of the oocytes that are gasified, identified and stored inside the mini tubes where their temperature is around $37.5^{\circ} \mathrm{C}$ to $38^{\circ} \mathrm{C}$ and are transported to the laboratory where the fecundation process took place.

Table 1. Morphological classification of oocytes as a function of cumulus oophorus complex (COC) and ooplasma.

\begin{tabular}{|c|c|c|}
\hline Classification & Cumulus cells & Ooplasma \\
\hline Grade I (GI) & $\begin{array}{c}\text { Compact } \mathrm{CCO}>3 \text { layers of cumulus } \\
\text { cells }\end{array}$ & Homogenous \\
\hline Grade II (GII) & $\begin{array}{c}\text { Compact } \mathrm{CCO}<3 \text { layers of cumulus } \\
\text { cells }\end{array}$ & Heterogenic (slightly) \\
\hline $\begin{array}{l}\text { Grade III (GIII) or partially } \\
\text { naked }\end{array}$ & $\begin{array}{c}\text { Removal of less than } 1 / 3 \text { of the } \\
\text { cumulus cells }\end{array}$ & \\
\hline Naked or Degenerate & No cells in the zona pelúcida & $\begin{array}{l}\text { Retroaction and } \\
\text { vaccination }\end{array}$ \\
\hline Cumulus expanded or atresic & Expansion & \\
\hline
\end{tabular}

Source: adapted from Lonergan et al. (1994)

The experimental design was in complete unbalanced blocks, considering the animal as parcel and the region as block. The blocks were composed of oocytes collected in 166, 40 and 32 Nelore cows, 60, 133 and 74 Senepol cows in regions 1, 2 and 3, respectively, making a total of 238 Nelore cows and 267 Senepol cows, totaling 505 cows experimental units. 
He statistical model used was:

$Y_{i j(j)}=\mu+r_{j}+b_{l(j)}+R_{i}+\varepsilon_{i j(j),}$

In which: $Y i j l(j)=$ observed value of race $\mathrm{i}$ in repetition $\mathrm{j}$ of block $1 ; \mu=$ overall mean effect; $\mathrm{rj}=$ random effect of repetition $\mathrm{j}$ in block $1, j=1,2, \ldots, \mathrm{r}) ; b j=$ random effect of block $1,1=$ region 1, 2 and 3; Ri = fixed effect of race $i, i=$ Nelore and Senepol; $\varepsilon i j=$ random error associated with each observation, assuming $\varepsilon \mathrm{ij} \sim \mathrm{NID}(0, \mathrm{I} \sigma 2 \varepsilon)$ and $\operatorname{I\sigma } 2 \varepsilon$ as the matrix of variance and covariance.

The counting data (Poisson distribution) were transformed into $(\mathrm{x}+1)$ and analyzed using the method of mixed models with special parametric structure in the covariance matrix, using the MIXED procedure of the SAS statistical software (SAS Studio, v. 9.4) (LITTELL et al., 2006) using the method of maximum restricted likelihood (REML). For the choice of the covariance matrix, the Akaike information criterion (AIC) was used (WOLFINGER, 1993) and the correction of the degrees of freedom was done using the method of Kenward and Roger (1997) $(\mathrm{DDFM}=\mathrm{KR})$. Treatment means were estimated by the mean of least squares (LSMEANS) and the comparison was made using the probability of difference (PDIFF) of Student's t test $(\mathrm{P}<$ $0.05)$.

\section{RESULTS AND DISCUSSION}

The classification of GI oocytes did not differ between the races $(\mathrm{P}=0,1401)$, presenting on average 0.28 oocytes per animal and a total of 139 aspirated oocytes (Table 2). However, GII differed between breeds $(\mathrm{P}=0,0063)$, in which the total number of oocytes and per animal in the Nelore breed was 50 and $68 \%$ higher than Senepol, respectively.

The GIII degree of maturity was affected by the breed $(\mathrm{P}=0,0089$; Table 2). Nelore presented a total and mean number of oocytes $9 \%$ and $22 \%$ higher than Senepol, respectively. In this degree of maturation are $91 \%$ of viable oocytes (GI, GII, and GIII oocytes). Thus, the viable oocytes were affected by the race $(\mathrm{P}=0,0191)$, in which Nelore was $13 \%$ higher in total and $26 \%$ higher in the average oocytes per animal.

The oocytes classified as atresic $(\mathrm{P}=0,7953)$ and denuded $(\mathrm{P}=0,2022)$ were not affected by the race (Table 2). On average, the animals presented 1.25 atresic oocytes and 3.38 denuded oocytes. Thus, the total number of non-viable oocytes (atresic and denuded) did not differ between the breeds $(\mathrm{P}=0,3555)$, presenting a total of 2338 and a mean of 4,63 non-viable oocytes per cow. The number of non-viable oocytes was $\sim 14 \%$ of the total oocytes aspirated. 
The total number of oocytes aspirated was affected by the breed $(\mathrm{P}=0,1401)$. Nelore was $25 \%$ higher than Senepol in the number of oocytes aspirated per cow. Nelore presented a difference (896 oocytes) 11\% higher than Senepol.

Table 2. Classification of oocysts distributed according to quality grade GI, GII and GIII (viable), atresic and denuded (non-viable), aspirated in donor cows of the Nelore and Senepol breeds in Mato Grosso.

\begin{tabular}{|c|c|c|c|c|c|c|c|}
\hline \multirow{3}{*}{ Variables } & \multicolumn{6}{|c|}{ Breeds } & \multirow{3}{*}{$P$-value } \\
\hline & \multicolumn{3}{|c|}{ Nelore } & \multicolumn{3}{|c|}{ Senepol } & \\
\hline & Means $^{\mathrm{a}} \pm \mathrm{EPM}^{\mathrm{b}}$ & Means ${ }^{\mathrm{c}}$ & Sum $^{\mathrm{d}}$ & Means $^{\mathrm{a}} \pm \mathrm{EPM}^{\mathrm{b}}$ & Means ${ }^{\mathrm{c}}$ & Sum $^{\mathrm{d}}$ & \\
\hline GI & $1,12 \pm 0,03 \mathrm{a}$ & 0,40 & 95 & $1,06 \pm 0,03 \mathrm{a}$ & 0,16 & 44 & 0.1401 \\
\hline GII & $1,79 \pm 0,07 \mathrm{a}$ & 2,84 & 675 & $1,50 \pm 0,07 \mathrm{~b}$ & 1,69 & 451 & 0,0063 \\
\hline GIII & $5,23 \pm 0,23 \mathrm{a}$ & 29,26 & 6963 & $4,80 \pm 0,22 b$ & 23,88 & 6376 & 0,0089 \\
\hline Viables & $5,48 \pm 0,24 \mathrm{a}$ & 32,49 & 7733 & $4,96 \pm 0,22 b$ & 25,73 & 6871 & 0,0191 \\
\hline Atrésicos & $1,40 \pm 0,08 \mathrm{a}$ & 1,19 & 283 & $1,37 \pm 0,08 \mathrm{a}$ & 1,31 & 349 & 0,7953 \\
\hline Naked & $2,02 \pm 0,09 \mathrm{a}$ & 3,79 & 903 & $1,90 \pm 0,08 \mathrm{a}$ & 3,01 & 803 & 0,2022 \\
\hline Unpredictable & $2,29 \pm 0,11 \mathrm{a}$ & 4,98 & 1186 & $2,16 \pm 0,09 \mathrm{a}$ & 4,31 & 1152 & 0,3555 \\
\hline Total & $5,89 \pm 0,25 \mathrm{a}$ & 37,47 & 8919 & $5,36 \pm 0,23 \mathrm{~b}$ & 30,05 & 8023 & 0,0209 \\
\hline
\end{tabular}

${ }^{a}$ Transformed mean $(\sqrt{ } \mathrm{x}+1) \pm$; ${ }^{\mathrm{b}}$ Standard error of the mean; ${ }^{\mathrm{c}}$ Real mean (number of oocytes aspirated per cow); and ${ }^{\mathrm{d}}$ Sum of oocytes aspirated in each breed. Averages with different letters on the line are different by Student's t test $(\mathrm{P}<0,05)$. Source: Prepared by the authors themselves, 2016.

Comparing the breeds over the months of collection (Figure 1), we observed that, regardless of the month, the Nelore breed presented higher quantities of viable and total oocytes than Senepol. In the months of January, February and December, Nelore was 50, 30 and $31 \%$ higher than Senepol in the total number of oocytes aspirated, respectively. This total is composed mainly of viable oocytes, which in January corresponded to $88 \%$ of the total, in which Nelore was $48 \%$ higher than Senepol. In October and November, months with the smallest differences between the breeds, Nelore was 5 and $6 \%$ in total and 10 and $4 \%$ higher than Senepol in viable oocytes. 
Figure 1. Number of oocytes aspirated during the months of collection in the Nelore and Senepol breeds in Mato Grosso.

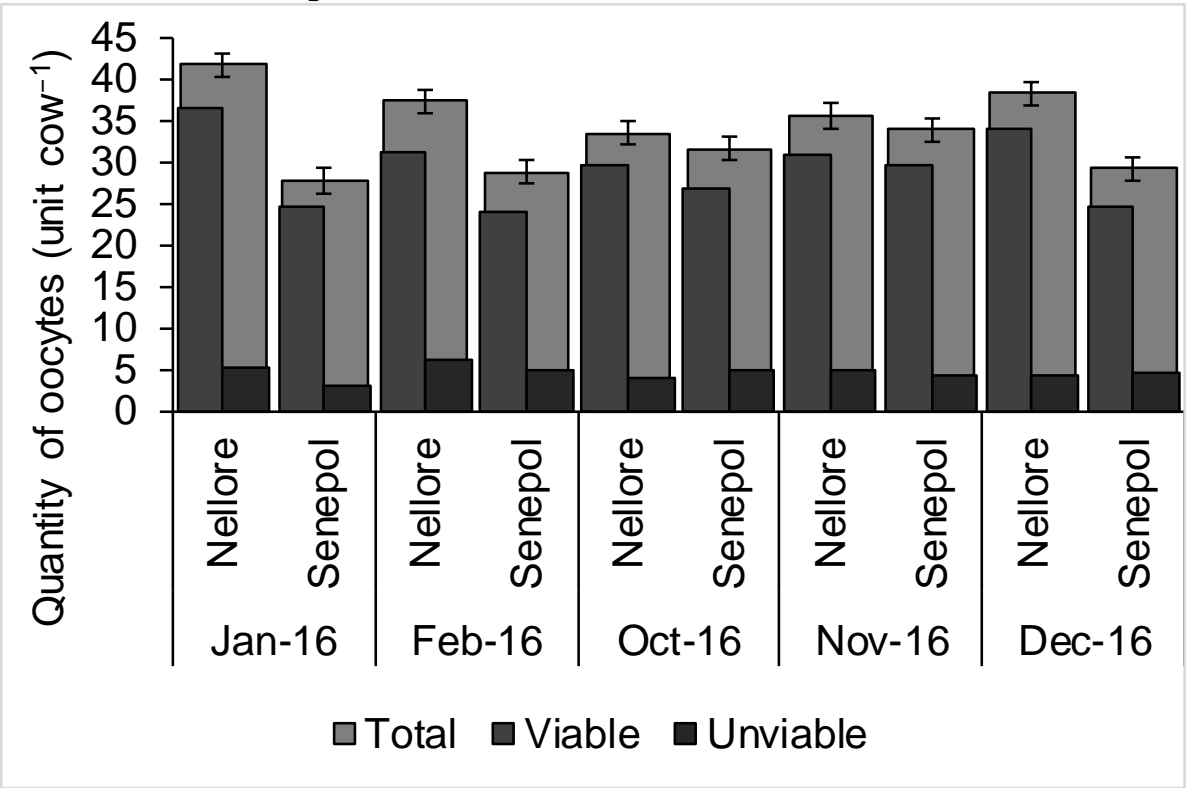

Source: Prepared by the authors themselves, 2016.

In both races, the largest collection of non-viable oocytes occurred in February (Figure 1), when Nelore was 25\% higher than Senepol. In this sense, the greatest difference was recorded for Nelore in January, 73\% higher than Senepol. In October and December, the Senepol breed had 24 and 5\% more oocytes than Nelore.

The ability of oocytes to develop in vitro and their viability depends exclusively on the cells of the cumulus, which is coated directly to the cytoplasm (ooplasm), allowing the transport of nutrients, the signals that control the metabolism, and the nuclear maturation, and cytoplasm (FERNANDES et al., 2001). The classification allows a visual evaluation of the oocytes and the quantity and appearance of cumulus cells and the uniformity of the ooplasm, in ways to select quality oocytes being viable for in vitro development (COSTA et al., 1997).

Compared to the total number of oocytes produced, the Senepol breed has low reproductive capacity in nelores, because the climatic conditions in the region are of transition from the spring-summer season, in rainy periods, hot with high temperatures and high humidity. We have shown that taurine breeds are few resistant to tropical climate, affecting the reproductive part of the animal. Zebu breeds obtain greater ability in thermo regulation of body temperature with lower metabolic rate and a greater ability in body heat loss than breeds of European origin (HANSEN, 2004). Another explanation for the resistance of high temperatures is that they contain greater amounts of sweat glands, with a coat that increases heat dissipation by solar radiation. (HUTCHINSON; BROWN, 1969; HANSEN, 2004)

Results obtained indicate that zebu breeds produce more total oocytes related to taurines, so that it was found for the Nelore breed that reached a statistically different amount than the 
Senepol breed. Work performed by Cruz et al. (2009), quantified the average number of oocytes aspirated from female zebuins (Nelore) and taurines (Devon) bred under pasture conditions and concluded that female zebuins provided the highest number of recovered oocytes, due to variability of the recovered extructures, and by the damage to oocyte integrity caused by puncture and excessive time from aspiration to vitrification process.

Due to the higher amount of oocytes produced by the Nelore matrices, it reflected in the higher capacity to produce good quality oocytes in GI, GII and GIII, meaning that there will be a higher amount of aspirated oocytes that will be viable for in vitro fertilization. The classification of degrees refers to oocyte morphology based on the coverage of cumulus cells to develop into a blastocyte, being found in degrees of atrophy or naked losing their ability to mature (LEIBFRIED; FIRST, 1979; WARD et al., 2000).

Senepol females produced smaller quantities of viable oocyte quality, and similar in the production of non-viable ones. This result demonstrates the low capacity of oocyte development. According to some authors, GI oocytes, GII to GIII, have a similar capacity to develop cumulus, only for naked morphology or (degeneration) that has its potency compromised to develop in vitro (LEIBFRIED; FIRST, 1979; LOOS et al., 1989; WARD et al., 2000).

Thus, the increase in body temperature or hyperthermia may compromise cell function resulting in physiological changes, compromising oocyte and embryo culture (HANSEN, 2004) reducing the rate of fertilization when in hot periods of the year such as summer (SARTORI et al., 2002). Probably it is related to the fact that heat is harmful affecting the steroidogenic capacity of follicles and their follicular dynamics, affecting the beginning of the antral stage of development and causing the reduction of dominance of the selected follicle (OZAWA et al., 2005; ROCHA et al., 2012).

Regarding the aspirations, after the months of January and February in (Figure 1), the animals go through a period of rest and soon after enters the winter and dry period, where the matrices go through seasonal periods with low quality fodder, being only supplemented by the energetic protein base. And when starting again between September and November the oocyte production is low compared to the months of January and February when the pastures are of better quality.

\section{CONCLUSION}

The results obtained in this work, we can conclude that among the breeds evaluated, the Nelore breed was superior in total oocyte quantities and in the classification of GI and GII, being superior in the quantities of viable oocytes compared to the Senepol breed. 


\section{ACKNOWLEDGEMENTS}

Thanks to ADE - Reprodution Cuiabá-MT for supporting the research, to the Federal Institute of Mato Grosso IFMT - Campus São Vicente and the Federal University of Mato Grosso UFMT Campus Cuiabá.

\section{REFERENCES}

AGOSTINHO, J. M. A.; LÉGA, E. Índice de recuperação de oócitos bovinos obtidos de ovários adquiridos em abatedouro como contribuição para os estudos de fecundação e produção de embriões in vitro. Nucleus Animalium, v.1, n.1, p.102-114, 2009.

BUENO, A. P.; BELTRAN, M. P. Produção in vitro de embriões bovinos. Revista Científica Eletrônica de Medicina Veterinária, v.6, p.1-7, 2008.

COSTA, E. P.; VAlE FILHO, V. R.; NOGUEIRA, J. C.; SÁ, W. F.; COSTA, A. H. A. Tipos morfológicos de oócitos bovinos. Arquivos Brasileiros de Medicina Veterinária e Zootecnia, v.49, n.4, p.417-424, 1997.

CRUZ, F. B.; MARTINS, L. T.; MARINHO, L. S. R.; FORELL, F.; VIEIRA, A. D.; MEZZALIRA, A. Aspiração folicular em vacas Bos taurus e Bos indicus e vitrificação dos oócitos em condições de campo. Revista de Ciências Agroveterinárias, v.8, n.2, p.184 -187, 2009.

FERNANDES, C. E; DODE, M. A. N.; GODOY, K.; RODOVALHO, N. Efeito estacional sobre características ovarianas e produção de oócitos em vacas Bos indicus no Mato Grosso do Sul. Brazilian Journal of Veterinary Research and Animal Science, v.38, n.3, p.131-135, 2001.

GONÇALVES, B. D.; FIGUEIREDO, J. R.; FREITAS, V. J. F. Biotécnicas aplicadas à Reprodução Animal. São Paulo: Varela, p. 195-226. 2002.

GONÇALVES, P. B. D.; BARRETA, M. H.; SANDRI, L. R.; FERREIRA, R.; ANTONIAZZI, A. Q. Produção in vitro de embriões bovinos: o estado da arte. Revista Brasileira de Reprodução Animal, v.31, p.212-217, 2007.

HANSEN, P. J. Physiological and cellular adaptations of zebu cattletothermal stress. Animal Reproduction Science, v.82-83, p.349-360, 2004.

HUTCHINSON, J. C.; BROWN, G. D. Penetrance of cattle coats by radiation. Journal of Applied Physiology, v.26, n.4, p.454-464, 1969.

KENWARD, M. G.; ROGER, J. H. Small Sample Inference for Fixed Effects from Restricted Maximum Likelihood. Biometrics, v.53, n.3, p.983-997, 1997.

KÖPPEN, W.; GEIGER, R. Klimate der Erde. Gotha: Verlagcondicionadas. Justus Perthes. 1928. 
LEAL, L. S.; OBA, E.; FERNANDES, C.A.C.; SA FILHO, O.G. Avaliação do corpo lúteo, contratilidade uterina e concentrações plasmáticas de progesterona e estradiol em receptoras de embriões bovinos. Ciência Animal Brasileira, v.10, n.1, p.174-183, 2009.

LEIBFRIED, L.; FIRST, N. L. Characterization of bovine follicular oocytes and their ability to mature in vitro. Journal of Animal Science, v. 48, n.1, p.76-86, 1979.

LITTELl, R. C. MILlIKEN, G.A., STROUP, W. W., WOLFINGER, R. D.; SCHABENBERGER, O. SAS for mixed model, 2th Ed., SAS Publishing, Cary, NC. 2006.

LONERGAN, P.; FAIR, T. In vitro-produced bovine embryos: dealing with the warts. Theriogenology, v.69, n.1, p.17-22, 2008.

LONERGAN, P.; MONAGHAN, P.; RIZOS, D.; BOLAND, M. P.; GORDON, I. Effect of follicle size on bovine oocyte quality and developmental competence following maturation, fertilization, and culture in vitro. Molecular Reproduction and Development, v.37, n.1, p.4853, 1994.

LOOS, F.; VLIET, C.; MAURIK, P.; KRUIP, A. M. Morphology of Immature Bovine Oocytes.Gamete Research, v.24, p.197-204, 1989.

LOWMAN, B. G.; SCOTT, N.; SOMERVILLE, S. Condition scoring beef cattle. Edinburgh: Scotland College of Agriculture, 8p., 1976.

MARCUZZO, F. F. N.; CARDOSO, M. R. D.; FARIA, T. G. Chuvas no cerrado da região centro-oeste do brasil: análise histórica e tendência futura. Ateliê Geográfico, v.6, n.2, p.112130, 2012.

MELLO, R. R. C.; FERREIRA, J. E.; SOUSA, S. L. G.; MELLO, M. R. B.; PALHANO, H. B. Fatores ligados à doadora que influenciam na produção de embriões in vitro (PIVE). Revista Brasileira de Reprodução Animal, v.40, n.2, p.51-57, 2016.

OZAWA, M.; TABAYASHI, D.; LATIEF, T. A.; SHIMIZU, T.; OSHIMA, I.; KANAI, Y. Alterations in follicular dynamics and steroidogenic abilities induced by heat stress during follicular recruitment in goats. Reproduction, v.129, p.621-630, 2005.

ROCHA, A.; RANDEL, R. D.; BROUSSARD, J. R.; LIM, J. M.; BLAIR, R. M.; ROUSSEL, J. D.; GODKE, R. A.; HANSEL, W. High environmental temperature and humidity decrease oocyte quality in Bos taurus but not in Bos indicus cows. Theriogenology, v.49, n.3, p.657-665, 1998.

ROCHA, D. R.; SALLES, M. G. F.; MOURA, A. A. A. N.; ARAÚJO, A. A. Impacto do estresse térmico na reprodução da fêmea bovina. Revista Brasileira de Reprodução Animal, v.36, n.1, p.18-24, 2012.

SARTORI, R.; SARTOR-BERGFELT, R.; MERTENS, S. A.; GUENTHER, J. N.; PARRISH, J. J.; WILTBANK, M. C. Fertilization and Early Embryonic Development in Heifers and Lactating Cows in Summer and Lactating and Dry Cows in Winter. Journal Dairy Science, v.85, p.2803$2812,2002$. 
STEPTOE, P. C.; EDWARDS, R. G. Birth after reimplantation of human embryo. Lancet, v.2, p.366, 1978.

VARAGO, F. C.; MENDONÇA, L. F.; LAGARES, M. A. Produção in vitro de embriões bovinos: estado da arte e perspectivas de uma técnica em constante evolução. Revista Brasileira de Reprodução Animal, v.32, p.100-109, 2008.

VIANA, J. H. M. Use of in vitro fertilization technique in the last decade and its effect on Brasizian embryo industry and animal production. Acta Sientiae Veterinariae, v.38, p.661-674. 2010.

WARD, F. A.; LONERGAN, P.; ENRIGHT, B. P.; BOLAND, M. P. Factors affecting recovery and quality of oogcytes for bovine embryo production in vitro using ovum pick-up technology. Thenogenology, v.54, p.433-446, 2000.

WOLFINGER, R. Covariance structure selection in general mixed models. Communications in Statistics and Computation, v.22, n.4, p.1079-1106, 1993. 